\title{
VARIABEL-VARIABEL YANG MEMPENGARUHI RETURN SAHAM PADA PERUSAHAAN PROPERTY DAN REAL ESTATE DI BEI
}

\author{
Kadek Ayu Silvia Yuliaratih ${ }^{1}$ \\ Luh Gede Sri Artini ${ }^{2}$
}

\author{
${ }^{1}$ Fakultas Ekonomi dan Bisnis Universitas Udayana (Unud), Bali, Indonesia \\ e-mail: silviatich@ gmail.com \\ ${ }^{2}$ Fakultas Ekonomi dan Bisnis Universitas Udayana (Unud), Bali, Indonesia
}

\begin{abstract}
ABSTRAK
Penelitian ini bertujuan untuk membuktikan secara empiris faktor-faktor Produk Domestik Bruto (PDB), nilai tukar rupiah, tingkat suku bunga SBI, inflasi, Return On Assets (ROA), Net Profit Margin (NPM), Earning Per Share (EPS) dan Price Earning Ratio (PER) terhadap return saham pada perusahaan property dan real estate diBursa Efek Indonesia pada tahun 2012-2016.Sampel penelitian ditentukan dengan metode purposive sampling dimana peneliti memiliki criteria atau tujuan tertentu terhadap sampel yang akan diteliti sebanyak 26 emiten yang termasuk dalam sektor property dan real estatedi PT Bursa Efek Indonesia Hasil penelitian ini adalah sebagai berikut: Produk Domestik Bruto, Net Profit Margin, Earning Per Share dan Price Earning Ratio berpengaruh positif dan signifikan terhadap return saham property dan real estate. Nilai tukar rupiah dan inflasi berpengaruh negatif dan signifikan terhadap return saham property dan real estate. Selanjutnya, tingkat suku bunga SBI dan Return On Assets berpengaruh positif dan signifikan terhadap return saham property.

Kata kunci: Return saham, Produk Domestik Bruto (PDB), nilai tukar rupiah, tingkat suku bunga SBI, inflasi, Return On Assets (ROA), Net Profit Margin (NPM), Earning Per Share (EPS) dan Price Earning Ratio (PER
\end{abstract}

\begin{abstract}
This study aims to prove empirically factors of Gross Domestic Product (GDP), Rupiah exchange rate, SBI interest rate, inflation, Return On Assets (ROA), Net Profit Margin (NPM), Earning Per Share (EPS) and Price Earning Ratio (PER) to stock return on property and real estate company in Indonesia Stock Exchange in 2012-2016. Research sample is determined by purposive sampling method where the researcher has certain criteria or objective to the sample to be researched as many as 26 emitters which included in property and real estate sector in PT Bursa Efek Indonesia The result of this research is as follows: Gross Domestic Product, Net Profit Margin, Earning Per Share and Price Earning Ratio have positive and significant effect to stock return of property and real estate. The rupiah exchange rate and inflation have a negative and significant effect on stock returns of property and real estate. Furthermore, the SBI interest rate and Return On Assets have a positive and significant effect on stock

Keywords: Return saham, Gross Domestic Product, exchange rate, SBI interest rate, inflation, Return On Assets (ROA), Net Profit Margin (NPM), Earning Per Share (EPS) dan Price Earning Ratio (PER)
\end{abstract}




\section{PENDAHULUAN}

Krisis ekonomi global saat ini diawali krisis finansial yang terjadi di Amerika Serikat sejak pertengahan 2007.Penyebabnya adalah kredit macet pada industri properti. Sebagai negara adidaya, krisis yang terjadi di Amerika Serikat (AS) akhirnya berpengaruh pula pada negara-negara lain terutama di Uni Eropa dan Asia termasuk di Indonesia (Edy Suandi,2009). Macetnya perputaran uang di sektor properti AS menyebabkan nilai tukar mengalami apresiasi (Triyono, 2008:156).Hal ini terlihat dari data nilai tukar rupiah sepanjang tahun 2013, sudah melemah sekitar 15 persen terhadap dollar Amerika Serikat.Pelemahan nilai tukar rupiah tersebut ternyata tidak memberikan keuntungan bagi perusahaan eksportir di Indonesia (Triyono, 2008:156-167).

Salah satu akibat yang ditimbulkan dari krisis finansial global terhadap ekonomi makro dapat tercermin dari tingkat suku bunga. Tingkat suku bunga dan kurs dollar yang tinggi akan berpengaruh terhadap sektor investasi. Investor akan cenderung menghindari investasi di pasar modal sebagai akibat dari kondisi makro yang kurang mendukung. Hal serupa juga pernah terjadi di Indonesia pada saat krisis ekonomi tahun 1997 dimana pelemahan nilai tukar rupiah terhadap dollar telah berdampak besar pada pasar modal di Indonesia.Dua contoh kasus diatas membuat fenomena pasar modal selalu menarik untuk dikaji lebih jauh.

Pasar modal memiliki peranan yang strategis yaitu menjadi indikator dalam perekonomian suatu negara sedang tumbuh.Meningkatknya perekonomian suatu negara tercermin dari meningkatnya volume perdagangan di pasar modal. 
Suad Husnan (2012:3) mengatakan bahwa analisis teknikal merupakan upaya untuk memperkirakan harga saham (kondisi pasar) dengan mengamati perubahan harga saham (kondisi pasar) di waktu yang lalu.Analisis fundamental adalah suatu pendekatan untuk menghitung nilai intrinsik saham biasa (common stock) dengan mengunakan data keuangan perusahaan. Tujuan investor menanamkan modalnya pada sekuritas saham adalah untuk mendapatkan return yang tinggi dengan tingkat risiko tertentu. Oleh karena itu, dalam melakukan investasi sekuritas saham investor akan lebih menyukai perusahaan yang dapat memberikan return yang lebih tinggi.

Seiring dengan meningkatnya aktivitas perdagangan, masyarakat dan investor membutuhkan informasi yang relevan mengenai kondisi perkembangan bursa saham. Salah satu informasi yang dapat digunakan adalah melalui indeks harga saham sebagai cerminan dari pergerakan harga saham Indeks sektoral BEI adalah sub indeks dari IHSG. Semua emiten yang tercatat di BEI diklasifikasikan ke dalam sembilan sektor menurut klasifikasi industri yang telah ditetapkan BEI, yang diberi nama JASICA (Jakarta Industrial Classifcation).

Kesembilan sektor tersebut yakni sektor-sektor primer (pertanian dan pertambangan), sektor-sektor sekunder (industri dasar dan kimia, aneka industri, industri barang konsumsi), dan sektor-sektor tersier (properti dan real estate, transportasi dan infrastruktur, keuangan, perdagangan, jasa dan investasi).

Salah satu sektor yang akan diteliti dalam penelitian ini adalah sektor properti. Sektor properti menjadi salah satu sektor yang penting di Indonesia.Sektor ini dianggap menjadi salah satu indikator kesehatan ekonomi suatu negara, dimana jatuh 
Kadek Ayu Silvia Yuliaratih, dan Luh Gede Sri Artini. Variabel-variabel yang mempengaruhi...

bangunnya perekonomian suatu negara dapat tercermin dari kondisi sektor propertinya. Industri properti dapat menjadi pendorong bagi kegiatan ekonomi karena meningkatnya kegiatan di bidang properti akan mendorong naiknya berbagai kegiatan di sektor-sektor lain yang terkait. Dalam hal ini sektor properti memiliki efek multiplier effect yakni dengan mendorong serangkaian aktivitas sektor ekonomi yang lain (Martinus, 2005).

Pertumbuhan sektor properti sangat sensitif terhadap indikator makro ekonomi, seperti pertumbuhan ekonomi, laju inflasi, tingkat suku bunga dan nilai tukar rupiah. Proyek pembangunan properti ini juga mencetak banyak lapangan pekerjaan dan menggerakkan berbagai industri lainnya. Sektor ini dipercaya oleh banyak negara sebagai obat mujarab untuk mempertahankan pertumbuhan ekonomi negara. Sektor ini juga menjadi indikator penting untuk menganalisis

Pada tahun 2011, terdapat pembahasan mengenai bubble property yang menjadi kekhawatiran yang hangat dibicarakan oleh para pelaku properti hingga saat ini. Hal ini mengemuka ketika mantan Menteri Keuangan saat itu, Agus Martowardoyo pada Berita Properti Bank Indonesia meminta pelaku sektor properti untuk mewaspadai terjadinya bubble property di Indonesia (www.bi.go.id, diakses September 2012). Bubble property adalah keadaan terjadinya kenaikan harga-harga properti secara tidak wajar dan terus menerus. Kondisi bubble propertyakan menjadikan harga-harga properti jatuh. Terjadinya over supply menjadikan pasar jenuh dan penyaluran kredit yang terlalu pasif, tidak tercapainya target inflasi dan akan di ikuti dengan 
ambruknya ekonomi secara menyeluruh sehingga akan beresiko menimbulkan resesi ekonomi nasional.

Analisis ekonomi perlu dilakukan karena adanya hubungan yang kuat antara apa yang terjadi pada lingkungan ekonomi makro dan kinerja suatu pasar modal. Kemampuan investor dalam memahami dan meramalkan kondisi ekonomi makro di masa datang akan sangat berguna dalam pembuatan keputusan investasi sehingga investor harus memperhatikan beberapa indikator ekonomi makro yang bias membantu dalam memahami dan meramalkan kondisi ekonomi makro.

Faktor-faktor ekonomi makro secara empiris telah terbukti mempunyai pengaruh terhadap perkembangan investasi di beberapa negara. Tandelilin (2010) merangkum beberapa faktor ekonomi makro yang berpengaruh terhadap investasi di suatu Negara, sebagai: tingkat pertumbuhan Produk Domestik Bruto (PDB), laju pertumbuhan inflasi, tingkat suku bunga dan nilai tukar mata uang (exchange rate).

Analisis Industri merupakan tahap kedua dalam analisis fundamental secara top-down approach. Dalam tahap ini, investor mencoba membandingkan kinerja dari berbagai industri dalam suatu lokasi (negara), untuk mengetahui jenis industri apa saja yang memiliki prospek menjanjikan. Selanjutnya berdasarkan analisis itu, investor bisa menggunakan informasi yang didapatkan sebagai masukan untuk mempertimbangkan peluang investasi dan return yang diharapkan kedepannya.

Dalam analisis industri, investor mencoba membandingkan kinerja berbagai industri unruk mengetahui industri. Melakukan analisis industri investor nantinya akan mendapatkan informasi sebagai masukan untuk memprtimbangkan saham- 
Kadek Ayu Silvia Yuliaratih, dan Luh Gede Sri Artini. Variabel-variabel yang mempengaruhi...

saham dari industry mana saja yang memiliki prospek menjanjikan kedepannya. Beberapa sektor industri memperoleh kenaikan laba yang diikuti dengan kenaikan return saham, namun pada beberapa sektor industri yang kenaikannya tidak diikuti dengan kemampuan untuk menghasilkan return saham yang meningkat. Sektor yang akan diamati kali ini adalah sektor industri property dan real estate, dimana perusahaan property dan real estate pada zaman ini sedang berkembang pesat. Perkembangan industri property saat ini juga menunjukkan pertumbuhan yang sangat meyakinkan.Hal ini ditandai dengan maraknya pembangunan perumahan, apartemen, perkantoran dan perhotelan.Disamping itu, perkembangan sektor property dan real estate sudah dapat dilihat di kota-kota besar bahkan sampai pedesaan.

Analisis perusahaan merupakan tahap terakhir untuk menentukan perusahaan perusahaan atau saham mana saja yang menguntungkan sehingga layak dijadikan pilihan investor untuk berinvestasi.Untuk melakukan analisis perusahaan, investor mendasarkan pada laporan keuangan dan rasio keuangan. Indikator ini sangat penting diperhatikan untuk mengetahui sejauh mana investasi yang akan dilakukan investor di suatu perusahaan mampu memberikan return yang sesuai dengan tingkat yang diisyaratkan investor. Munawir (2008) mengelompokkan rasio keuangan ke dalam empat rasio yaitu rasio profitabilitas, likuiditas, solvabilitas, aktivitas.Rasio-rasio keuangan tersebut digunakan untuk menjelaskan kekuatan dan kelemahan dari kondisi keuangan suatu perusahaan serta dapat memprediksi harga saham di pasar modal. 
Rasio-rasio yang digunakan di dalam penelitian ini adalah rasio profitabilitas dan rasio pasar yang bertujuan untuk menunjukkan kemampuan perusahaan dalam memperoleh laba dan sering digunakan untuk memprediksi harga saham yaitu Return On Asset (ROA), Earning Per Share (EPS), Price Earning Ratio (PER) dan NetProfit Margin (NPM).

Pada penelitian Sangkyun (1997) yang menyatakan bahwa PDB berpengaruh secara positif dan signifikan terhadap return saham, sedangkan variabel lain tidak berpengaruh. Penelitian Chiarella \& Gao (2004) menemukan hasil bahwa PDB berpengaruh secara signifikan terhadap return saham.

Penelitian tentang inflasi terhadap return saham pernah dilakukan oleh Hooker (2004) yang menemukan bahwa tingkat inflasi berpengaruh secara positif terhadapreturn saham. Hasil tersebut berbeda dengan hasil penelitian yang dilakukan oleh Oumadan Muriu (2014), Okwuchukwu (2014) yang memberikan hasil bahwa inflasi berpengaruh negatif signifikan terhadap return saham.

Penelitian tentang tingkat suku bunga terhadap return saham pernah diteliti oleh Ouma dan Muriu (2014), yang menunjukkan hasil bahwa tingkat suku bunga tidak berpengaruh terhadap return saham. Hasil penelitian tersebut berbeda dengan penelitian yang dilakukan oleh Hayat dan Nisar Ahmed (2014) yang menunjukkan hasil tingkat suku bunga berpengaruh negatif dan signifikan terhadap return saham.

Penelitian tentang nilai tukar terhadap return pernah dilakukan oleh Ouma, Muriu (2014), Onono (2014) yang memberikan hasil nilai tukar berpengaruh negative signifikan terhadap return saham. Hasil penelitian ini berbeda dengan yang dilakukan 
oleh Okwuchukwu (2014), Hayat dan Nisar Ahmed (2014), yang menyatakan bahwa nilai tukar berpengaruh positif dan signifikan terhadap return saham.

Sunarto (2001) menunjukkan bahwa ROA berpengaruh negatif signifikan terhadap return saham pada periode 1998/1999, penelitian yang dilakukan oleh Agus Harjito dan Rangga Aryayoga (2009) menunjukkan ROA berpengaruh negatif dan tidak signifikan terhadap return saham sedangkan menurut tesis yang diteliti Mila Christanty (2009), Yeye Susilowati (2011) menunjukkan ROA mempunyai pengaruh yang positif dan tidak signifikan terhadap return saham. Tetapi menurut Syahib Natarsyah (2000), Pancawati Hardiningsih dkk (2001), Asbi Rachman Faried (2008) dan Ratna Prihantini (2009).menunjukkan ROA berpengaruh positif signifikan terhadap return saham. Oleh karena itu, perlu dilakukan penelitian lebih lanjut untuk mengetahui bagaimana pengaruh ROA terhadap return saham.

Penelitian Net Profit Margin (NPM) yang diteliti oleh Asyik dan Sulistyo (2000), Mila Christanty (2009), Agus Harjito dan Rangga Aryayoga (2009), Yeye Susilowati (2011) dimana hasil penelitian menunjukkan bahwa NPM berpengaruh signifikan terhadap return saham. Sedangkan Machfoedz (1994) menunjukkan hasil bahwa NPM tidak berpengaruh signifikan terhadap laba perusahaan. Begitu juga dengan penelitian yang dilakukan Asbi Rachman Faried (2008), Nicky Nathaniel (2008) yang menunjukkan bahwa NPM berpengaruh negatif dan tidak signifikan terhadap return saham.

Penelitian yang dilakukan Tendi Haruman dkk (2005) dan Mila Christanty (2009) menunjukkan bahwa EPS dan PER berpengaruh positif dan signifikan 
terhadap tingkat pengembalian saham. Namun hasil penelitian tesis yang dilakukan Octasari (2006) yang diulas oleh Septiana Rizky Kusumastuti (2009) menunjukkan hasil bahwa EPS dan PER berpengaruh negatif tetapi tidak signifikan terhadap return saham. Tetapi pada penelitian yang dilakukan oleh Yeye Susilowati (2011), Nicky Nathaniel (2008) EPS berpengaruh positif tetapi tidak signifikan sedangkan PER berpengaruh negatif dan tidak signifikan terhadap return saham.

Permasalahan dalam penelitian ini timbul karena adanya research gap yang menunjukkan hasil penelitian yang berbeda- beda dan adanya kondisi yang kontradiktif dengan fakta empiris antara variabel-variabel yang diteliti terhadap return saham.Hal ini mengakibatkan pemahaman mengenai faktor- faktor yang berpengaruhterhadap return saham sangat terbatas dan memerlukan justifikasi lebih mendalam.

Pertumbuhan ekonomi memiliki hubungan positif terhadap return saham, karena dengan menigkatnya pertumbuhan ekonomi akan mengakibatkan meningkatnya permintaan saham dan pada akhirnya akan mengakibatkan menigkatnya harga saham. Meningkatnya pertumbuhan ekonomi akan merubah pola investasi suatu negara. Salah satu indikator meningkatnya pertumbuhan ekonomi adalah meningkatnya GDP yang merupakan suatu kenaikkan output perkapita jangka panjang (Thobarry,2009).

Meningkatnya kinerja ekonomi yang dicerminkan oleh pertumbuhan PDB, investor cenderung akan lebih banyak berinvestasi di pasar modal. Dengan meningkatnya pertumbuhan PDB juga dapat mengakibatkan naiknya daya beli 
masyarakat yang imbasnya bisa saja dirasakan oleh pasar saham (Sangkyun Park, 1997).

H1 : Terdapat pengaruh Positif dan signifikan PDB terhadap return saham sektor property dan real estate.

Menurunnya kurs Dollar terhadap rupiah berpengaruh positif terhadap ekonomi dan pasar modal, sebaliknya kurs dollar terhadap rupiah berpengaruh negatif (Farid Harianto, 2008). Melemahnya rupiah akan menyebabkan pasar modal dalam negeri kurang menarik karena adanya risiko nilai tukar yang menyebabkan penurunan nilai investasi dan mempunyai hubungan negatif terhadap return saham. Sebaliknya, hubungan antara nilai tukar dollar terhadap rupiah bisa saja berpengaruh positif bila investor berasal dari luar negeri dan menggunakan mata uang asing sehingga semakin terdepresiasinya mata uang rupiah akan menyebabkan investor luar cenderung melepas mata uang asingnya untuk membeli saham yang harganya turun karena pengaruh kurs mata uang. (Thobarry, 2009)

H2 : Terdapat pengaruh negatif dan signifikan nilai tukar rupiah terhadap dolar pada return saham sektor property dan real estate.

Suku bunga memiliki hubungan negatif terhadap return saham. Hal ini disebabkan apabila tingkat suku bunga meningkat, orang cenderung untuk menabung daripada menginvestasikan modalnya dengan harapan risiko yang diharapkan lebih kecil dibandingkan bila menginvestasikan modalnya dalam bentuk saham. Jika tingkat bunga turun, investor cenderung lebih suka investasi dengan membeli saham 
sehingga permintaan saham akan meningkat dan akan mendorong peningkatan return saham. (Thobarry, 2009)

H3 : Terdapat pengaruh negatif dan signifikan suku bunga terhadap returnsaham sektorproperty dan real estate.

Tandelilin (2010), menyatakan bahwainflasi merupakan kecenderungan terjadinyapeningkatan harga produk - produk secara keseluruhan.Inflasi yang tinggi mengurangitingkat pendapatan riil yang diperoleh investordari investasi.

Tingkat inflasi yang tinggi memiliki hubungan yang negatif terhadap indeks return saham. Jika peningkatan biaya faktor produksi lebih tinggi dari pengingkatan harga yang dapat dinikmati oleh perusahaan, profitabilitas perusahaan akan menurun (Farid Harianto dalam Thobarry (2009)), menyebabkan efek ekuitas menjadi kurang kompetitif sehingga berdampak pada penurunan return saham di pasar modal. (Thobarry, 2009).Sebaliknya, jika tingkat inflasi suatu negara mengalami penurunan maka hal ini merupakan sinyal yang positif bagi investor seiring dengan turunnya resiko daya beli uang dan resiko penurunan pendapatan riil.

H4 : Terdapat pengaruh negatif dan signifikan antara tingkat inflasi terhadap return saham sektor property dan real estate.

Return On Assets (ROA) yang semakin meningkat menunjukkan kinerja perusahaanyang semakin baik dan para pemegang saham akan memperolehkeuntungan dari deviden yang diterima semakin meningkat (Hardiningsihdalam Prihantini, 2009). Dengan semakin meningkatnya deviden yangakan diterima oleh para pemegang saham, merupakan daya tarik bagi 
Kadek Ayu Silvia Yuliaratih, dan Luh Gede Sri Artini. Variabel-variabel yang mempengaruhi...

parainvestor dan atau calon investor untuk menanamkan dananya keperusahaan tersebut.

Dengan semakin besarnya daya tarik tersebut makabanyak investor yang menginginkan saham perusahaan tersebut. Jikapermintaan atas saham suatu perusahan semakin banyak maka returnsahamnya akanmeningkat. Dengan meningkatnya return saham makareturn yang diperoleh investor dari saham tersebut juga meningkat. Hal inidisebabkan karena return merupakan selisih antara return saham periodesaat ini dengan return saham sebelumnya (Natarsyah dalam Prihantini,2009). Hal ini sejalan dengan pendapat dari Ang (1997) yang menyatakanbahwa keuntungan perusahaan yang semakin meningkat memberikan tanda bahwa kekuatan operasional dan keuangan perusahaan semakinmembaik, sehingga memberikan pengaruh positif terhadap ekuitas(Prihantini, 2009).

Pernyataan tersebut sejalan dengan penelitian dari I.G.K.A Ulupui (2005) serta Amir Haghiri dan Soleyman Haghiri (2012) yang menyatakan bahwa ROA memiliki pengaruh positif dan signifikan terhadap return saham

H5 : Terdapat pengaruh positif dan signifikan antara Return On Assets (ROA) terhadap return saham sektor property dan real estate.

Net Profit Margin merupakan rasio antara laba bersih setelah pajak (net income after tax) terhadap total penjualan (sales). Rasio ini mengukur kemampuan perusahaan menghasilkan pendapatan bersihnya terhadap total penjualan yang dicapai oleh perusahaan. Jadi kinerja keuangan perusahaan dalam menghasilkan laba bersih atas penjualan semakin meningkat maka hal ini kan berdampak pada meningkatnya 
pendapatan yang akan diterima oleh para pemegang saham. NPM semakin meningkat menggambarkan kinerja perusahaan yang semakin baik dan keuntungan yang diperoleh pemegang saham akan meningkat pula. Menurut Robert Ang (1997).

H6 : Terdapat pengaruh positif dan signifikan antara NPM terhadap return saham sektor property dan real estate.

Salah satu indikator keberhasilan suatu perusahaan ditunjukkan oleh besarnya Earning per Share (EPS) dari perusahaan yang bersangkutan. Earning per Share (EPS) merupakan rasio perbandingan antara laba bersih sebelum pajak dengan harga per lembar saham.Earning per Share (EPS) menunjukkan seberapa besar keuntungan yang diberikan perusahaan kepada investor dari setiap lembar saham yang dimilikinya. Pada umumnya, investor aka mengharapkan manfaat dari investasinya dalam bentuk laba per lembar saham, sebab Earning per Share (EPS) ini menggambarkan jumlah keuntungan yang diperoleh untuk setiap lembar saham biasa Sedangkan jumlah Earning per Share (EPS) yang akan didistribusikan kepada investor saham tergantung pada kebijakan perusahaan dalam hal pembayaran deviden (Mulyono, 2000).

Menurut Fahrudin dan Hadianto (2001), Earning per Share (EPS) mengukur besarnya laba yang diberikan kepada pemegang saham. Sedangkan Chen et al (2006) mengungkapkan bahwa Earning per Share (EPS) merupakan salah satu indikator yang signifikan dalam model prediksi untuk menguji kegunaan rasio finansial dalam memprediksi kegagalan investasi di China. Eljelly dan Alghurair (2001), Aloysius (2004) dan Chen (2006) menunjukkan bahwa Earning per Share (EPS) merupakan 
Kadek Ayu Silvia Yuliaratih, dan Luh Gede Sri Artini. Variabel-variabel yang mempengaruhi...

variable yang positif dan signifikan dalam menerangkan perubahan return saham. Berdasarkan uraian di atas maka dapat diajukan hipotesis:

H7 : Earning per Share (EPS) berpengaruh positif dan signifikan terhadap ReturnSaham sektor property dan real estate

Price Earning Ratio (PER) merupakan rasio antara return saham dengan pendapatan setiap lembar saham, dan merupakan indikator perkembangan atau pertumbuhan perusahaan di masa yang akan datang (prospects of the firm). Semakin tinggi rasio PER, semakin tinggi pertumbuhan laba yang diharapkan oleh pemodal. Menurut Tendy dkk (2005) dan Mila Christanty (2009) PER berpengaruh positif dan signifikan terhadap return saham.

H8 : Price Earning Ratio (PER) berpengaruh positif dan signifikan terhadap ReturnSaham sektor property dan real estate.

\section{METODE PENELITIAN}

Penelitian ini merupakan penelitian eksplanatori dengan pendekatan kuantitatif. Adapun penelitian eksplanatori menurut Sugiyono (2012) adalah penelitian yang menjelaskan hubungan kausal antara variabel-variabel yang mempengaruhi hipotesis, maka dalam penelitian ini nantinya akan dijelaskan mengenai adanya hubungan interaktif atau timbal balik antara variabel yang akan diteliti dan sejauh mana hubungan tersebut saling mempengaruhi. Variabel yang digunakan dalam penelitian ini adalah, variabel dependent yaitu return saham, dan variabel independent adalah Produk Domestik Bruto (PDB), nilai tukar rupiah (kurs), tingkat suku bunga SBI, 
inflasi, Return On Assets (ROA), Net Profit Margin (NPM), Earning Per Share (EPS) dan Price Earning Ratio (PER).

Sampel dalam penelitian ini diambil menggunakan teknik purposive sampling karena jumlah pasti dari populasi tidak diketahui,dimana sample harus memenuhi kriteria: 1). Perusahaan properti yang telah dan masih tercatat (listed) di BEI pada Januari tahun 2012 s/d. Desember 2016; 2). Perdagangan saham emiten tidak pernah di suspendselama lebih dari satu bulan; 3). Saham diperdagangkan minimal 1 bulan sekali.Berdasarkan Kriteria yang ditemukan terdapat 26 perusahaan Properti dan Realestate yang datanya sesuai dengan kebutuhan penelitian ini

Teknik analisis data yang digunakan adalah analisis data kuantitatif, untukmemperkirakansecarakuantitatippengaruhdaribeberapa variable independensecarabersama-samamaupun secara sendiri-sendiriterhadap variable dependen.Hubunganfungsionalantarasatu variable dependent dengan variable independendapatdilakukandenganregresibergandadanmenggunakan data gabunganantaracross section dantime series.

\section{HASIL DAN PEMBAHASAN}

Analisis regresi linier berganda dalam penelitian ini dipergunakan untukmengetahui ada tidaknya pengaruh variabel bebas Produk Domestik Bruto (PDB), Nilai tukar(Kurs), suku bunga (SBI), inflasi, Return On Asset (ROA), Net Profit Margin (NPM), Earning Per Share (EPS) dan Price Earning Ratio (PER) terhadap ReturnSaham yang dinyatakan sebagai berikut:

$Y=a+b 1 \times 1 \times 2+b 3 \times 3+b 4 \times 4+b 5 \times 5+b 6 \times 6+b 7 \times 7+b 8 \times 8+e \ldots$ 
Kadek Ayu Silvia Yuliaratih, dan Luh Gede Sri Artini. Variabel-variabel yang mempengaruhi...

Berdasarkan uji statistik diperoleh hasil regresi linier berganda sebagai berikut:

\section{Tabel 1.}

Hasil Uji Regresi Linier Berganda

\begin{tabular}{|c|c|c|c|c|c|c|c|c|}
\hline & \multirow[t]{2}{*}{ Model } & \multicolumn{2}{|c|}{$\begin{array}{l}\text { Unstandarized } \\
\text { Coefficients }\end{array}$} & \multirow{2}{*}{$\begin{array}{c}\text { Standarized } \\
\text { Coefficients } \\
\text { Beta }\end{array}$} & \multirow[t]{2}{*}{$\mathrm{t}$} & \multirow[t]{2}{*}{ Sig. } & \multicolumn{2}{|c|}{ Collinearity Statistics } \\
\hline & & B & $\begin{array}{l}\text { Std. } \\
\text { Eror }\end{array}$ & & & & Tolerance & VIF \\
\hline \multirow[t]{9}{*}{1} & Constant & -2.082 & 2.236 & & -.931 & .354 & & \\
\hline & PDB & .004 & .000 & .191 & 2.190 & .030 & .146 & 6.830 \\
\hline & KURS & -.001 & .000 & -.158 & -2.335 & .021 & .245 & 4.085 \\
\hline & SBI & .070 & .192 & .043 & .366 & .715 & .177 & 5.649 \\
\hline & INFLASI & -.160 & .052 & -.196 & -3.064 & .003 & .272 & 3.682 \\
\hline & $\mathrm{ROA}$ & .008 & .008 & .039 & .997 & .321 & .724 & 1.381 \\
\hline & NPM & .007 & .000 & .783 & 17.022 & .000 & .527 & 1.898 \\
\hline & EPS & .003 & .000 & .084 & 2.173 & .032 & .748 & 1.337 \\
\hline & PER & .004 & .001 & .156 & 3.484 & .001 & .558 & 1.791 \\
\hline
\end{tabular}

Hasil pengujian persamaan regresi tersebut dapat dijelaskan sebagai berikut:

\section{Return Saham $=-2,082+0,004$ PDB - 0,001Kurs + 0,070SBI -0,160Inf + 0,008ROA +0,007NPM + 0,003EPS + 0,004PER + e}

Nilai konstanta sebesar -2,082 menunjukkan jika skor variabel Produk Domestik Bruto (PDB), Nilai tukar(Kurs), suku bunga (SBI), inflasi, Return On Asset (ROA), Net Profit Margin (NPM), Earning Per Share (EPS) dan Price Earning Ratio (PER) dianggap tidak ada atau sama dengan 0 , maka skor return saham akan semakin berkurang.

Produk Domestik Bruto (PDB) mempunyai koefisien regresi sebesar 0,004 artinya apabila variabel bebas lainnya dianggap konstan maka meningkatnya Produk Domestik Bruto (PDB) sebesar 1 persen akan diikuti oleh meningkatnya return saham sebesar 0,004 persen. 
Nilai tukar (Kurs) mempunyai koefisien regresi sebesar -0,001 artinya apabila variabel independent lainnya dianggap konstan maka meningkatnya Nilai tukar (Kurs) sebesar 1 persen akan diikuti oleh menurunnya return saham sebesar 0,001 persen.

Suku bunga (SBI) mempunyai koefisien regresi sebesar 0,070 artinya apabila variabel independent lainnya dianggap konstan maka meningkatnya Suku bunga (SBI) sebesar 1 persen akan diikuti oleh meningkatnya return saham sebesar 0,070 persen.

Inflasi mempunyai koefisien regresi sebesar -0,160 artinya apabila variabel independent lainnya dianggap konstan maka meningkatnya Inflasi sebesar 1 persen akan diikuti oleh menurunnya return saham sebesar 0,160 persen

Return On Asset (ROA) mempunyai koefisien regresi sebesar 0,008 artinya apabila variabel independent lainnya dianggap konstan maka meningkatnya Return On Asset (ROA) sebesar 1 persen akan diikuti oleh meningkatnya return saham sebesar 0,008 persen

Net Profit Margin (NPM) mempunyai koefisien regresi sebesar 0,007 artinya apabila variabel independent lainnya dianggap konstan maka meningkatnya rasio $\mathrm{Net}$ Profit Margin (NPM) sebesar 1 persen akan diikuti oleh meningkatnya return saham sebesar 0,007 persen

Earning Per Share (EPS) mempunyai koefisien regresi sebesar 0,003 artinya apabila variabel independent lainnya dianggap konstan maka meningkatnya Earning 
Kadek Ayu Silvia Yuliaratih, dan Luh Gede Sri Artini. Variabel-variabel yang mempengaruhi...

Per Share (EPS) sebesar 1 persen akan diikuti oleh meningkatnya return saham sebesar 0,003 persen

Price Earning Ratio (PER) mempunyai koefisien regresi sebesar 0,004 artinya apabila variabel independent lainnya dianggap konstan maka meningkatnya Price Earning Ratio (PER) sebesar 1 persen akan diikuti oleh meningkatnya return saham sebesar 0,004 persen

Tabel 2.

\section{Hasil Uji F pada Tabel Anova}

\begin{tabular}{ccccccc}
\hline \multicolumn{2}{l}{ Model } & $\begin{array}{c}\text { Sum of } \\
\text { Squares }\end{array}$ & df & Mean & F & Sig. \\
& & & Square & & .000 \\
\hline \multirow{2}{*}{1} & Regression & 136.355 & 8 & 17.044 & 97.071 & \\
& Residual & 21.246 & 121 & .176 & & \\
& Total & 157.601 & 129 & & & \\
\hline
\end{tabular}

Sumber : Data diolah, 2017

Berdasarkan Tabel 2Pengujian secara simultan Produk Domestik Bruto (PDB), Nilai tukar(Kurs), suku bunga (SBI), inflasi, Return On Asset (ROA), Net Profit Margin (NPM), Earning Per Share (EPS) dan Price Earning Ratio (PER) terhadap Return saham:

Berdasarkan tabel diperoleh nilai $F_{\text {hitung sebesar 97,071 dengan nilai }}$ probabilitas $(\mathrm{sig})=0,000$. Nilai $F_{\text {hitung }}(97,071)>F_{\text {tabel }}(2,09)$, dan nilai sig. lebih kecil dari nilai probabilitas 0,05 atau nilai $0,000<0,05$; maka $\mathrm{H}_{01}$ diterima, berarti secara bersama-sama (simultan) Produk Domestik Bruto (PDB), Nilai tukar(Kurs), suku bunga (SBI), inflasi, Return On Asset (ROA), Net Profit Margin (NPM), Earning Per Share (EPS) dan Price Earning Ratio (PER) berpengaruh signifikan terhadap Return saham. 
Tabel 3.

Hasil Uji t

\begin{tabular}{|c|c|c|c|c|c|c|c|c|}
\hline \multicolumn{2}{|r|}{ Model } & \multicolumn{2}{|c|}{$\begin{array}{l}\text { Unstandarized } \\
\text { Coefficients }\end{array}$} & \multirow{2}{*}{$\begin{array}{c}\text { Standarized } \\
\text { Coefficients } \\
\text { Beta }\end{array}$} & \multirow[t]{2}{*}{$\mathrm{t}$} & \multirow[t]{2}{*}{ Sig. } & \multicolumn{2}{|c|}{ Collinearity Statistics } \\
\hline & & $\mathrm{B}$ & $\begin{array}{l}\text { Std. } \\
\text { Eror }\end{array}$ & & & & Tolerance & VIF \\
\hline \multirow[t]{9}{*}{1} & Constant & -2.082 & 2.236 & & -.931 & .354 & & \\
\hline & PDB & .004 & .000 & 191 & 2.190 & .030 & .146 & 6.830 \\
\hline & KURS & -.001 & .000 & -.158 & -2.335 & .021 & .245 & 4.085 \\
\hline & SBI & .070 & .192 & .043 & . 366 & .715 & .177 & 5.649 \\
\hline & INFLASI & -.160 & .052 & -.196 & -3.064 & .003 & .272 & 3.682 \\
\hline & ROA & .008 & .008 & .039 & 997 & .321 & .724 & 1.381 \\
\hline & NPM & .007 & .000 & .783 & 17.022 & .000 & .527 & 1.898 \\
\hline & EPS & .003 & .000 & .084 & 2.173 & .032 & .748 & 1.337 \\
\hline & PER & .004 & .001 & .156 & 3.484 & .001 & .558 & 1.791 \\
\hline
\end{tabular}

Sumber : Data diolah, 2017

Berdasarkan hasil uji t pada Tabel 3 maka dapat dijelaskan hasil pengujian hipotesis sebagai berikut:

Variabel $\mathrm{X}_{1}$ pada tabel 3 mempunyai nilai signifikan sebesar 0,030 dan nilai koefisiennya sebesar 0.004.Penelitian ini alpha $(\alpha)$ yang digunakan adalah 5\% (0.05). Variabel $\mathrm{X}_{1}$ mempunyai nilai signifikan lebih kecil dibandingkan alpha $(\alpha)$ yaitu $0.030<0.05$, maka memberikan penjelasan bahwa variabel $\mathrm{X}_{1}$ mempunyai pengaruh signifikan terhadap return saham sektor property dan real estate. Sedangkan, nilai koefisien yang bertanda Positif (+) dapat diartikan bahwa variabel $\mathrm{X}_{1}$ berpengaruh secara positif terhadap return saham sektor property dan real estate, dengan demikian menolak Ho dan menerima $H_{1}$.

Variabel $\mathrm{X}_{2}$ pada tabel 3 mempunyai nilai signifikan sebesar 0.021 dan nilai koefisiennya sebesar -0.001.Penelitian ini alpha $(\alpha)$ yang digunakan adalah 5\% (0.05). Variabel $\mathrm{X}_{2}$ mempunyai nilai signifikan lebih kecil dibandingkan alpha $(\alpha)$ yaitu $0.021<0.05$, maka memberikan penjelasan bahwa variabel $\mathrm{X}_{2}$ mempunyai 
Kadek Ayu Silvia Yuliaratih, dan Luh Gede Sri Artini. Variabel-variabel yang mempengaruhi...

pengaruh signifikan terhadap return saham sektor property dan real estate. Sedangkan, nilai koefisien yang bertanda negatif (-) dapat diartikan bahwa variabel $\mathrm{X}_{2}$ berpengaruh secara negatif terhadap return saham sektor property dan real estate, dengan demikian menolak Ho dan menerima $\mathrm{H}_{2}$.

Variabel $\mathrm{X}_{3}$ pada tabel 3 mempunyai nilai signifikan sebesar 0,715 dan nilai koefisiennya sebesar 0.070.Penelitian ini alpha $(\alpha)$ yang digunakan adalah 5\% (0.05). Variabel $\mathrm{X}_{3}$ mempunyai nilai signifikan lebih besar dibandingkan alpha $(\alpha)$ yaitu $0.070>0.05$, maka memberikan penjelasan bahwa variabel $\mathrm{X}_{3}$ tidak mempunyai pengaruh signifikan terhadap return saham sektor property dan real estate. Sedangkan, nilai koefisien yang bertanda Positif (+) dapat diartikan bahwa variabel $\mathrm{X}_{3}$ berpengaruh secara positif terhadap return saham sektor property dan real estate, dengan demikian menerima Ho dan menolak $\mathrm{H}_{3}$.

Variabel $\mathrm{X}_{4}$ pada tabel 3 mempunyai nilai signifikan sebesar 0,003 dan nilai koefisiennya sebesar -0.160.Penelitian ini alpha $(\alpha)$ yang digunakan adalah 5\% (0.05). Variabel $\mathrm{X}_{4}$ mempunyai nilai signifikan lebih kecil dibandingkan alpha $(\alpha)$ yaitu $0,003<0.05$, maka memberikan penjelasan bahwa variabel $\mathrm{X}_{4}$ mempunyai pengaruh signifikan terhadap return saham sektor property dan real estate. Sedangkan, nilai koefisien yang bertanda negatif (-) dapat diartikan bahwa variabel $\mathrm{X}_{4}$ berpengaruh secara negatif terhadap return saham sektor property dan real estate, dengan demikian menolak Ho dan menerima $H_{4}$ 
Variabel $\mathrm{X}_{5}$ pada tabel 3 mempunyai nilai signifikan sebesar 0,321 dan nilai koefisiennya sebesar 0.008.Penelitian ini alpha $(\alpha)$ yang digunakan adalah 5\% (0.05). Variabel $\mathrm{X}_{5}$ mempunyai nilai signifikan lebih besar dibandingkan alpha $(\alpha)$ yaitu $0,321>0.05$, maka memberikan penjelasan bahwa variabel $\mathrm{X}_{5}$ tidak mempunyai pengaruh signifikan terhadap return saham sektor property dan real estate. Sedangkan, nilai koefisien yang bertanda Positif (+) dapat diartikan bahwa variabel $\mathrm{X}_{5}$ berpengaruh secara positif terhadap return saham sektor property dan real estate, dengan demikian menerima Ho dan menolak $\mathrm{H}_{5}$

Variabel $\mathrm{X}_{6}$ pada tabel 3 mempunyai nilai signifikan sebesar 0,000 dan nilai koefisiennya sebesar 0.007. Penelitian ini alpha $(\alpha)$ yang digunakan adalah 5\% (0.05). Variabel $\mathrm{X}_{6}$ mempunyai nilai signifikan lebih kecil dibandingkan alpha $(\alpha)$ yaitu $0.000<0.05$, maka memberikan penjelasan bahwa variabel $\mathrm{X}_{6}$ mempunyai pengaruh signifikan terhadap return saham sektor property dan real estate. Sedangkan, nilai koefisien yang bertanda Positif (+) dapat diartikan bahwa variabel $\mathrm{X}_{6}$ berpengaruh secara positif terhadap return saham sektor property dan real estate, dengan demikian menolak Ho dan menerima $H_{6}$.

Variabel $\mathrm{X}_{7}$ pada tabel 3 mempunyai nilai signifikan sebesar 0,032 dan nilai koefisiennya sebesar 0.003. Penelitian ini alpha $(\alpha)$ yang digunakan adalah 5\% (0.05). Variabel $\mathrm{X}_{7}$ mempunyai nilai signifikan lebih kecil dibandingkan alpha $(\alpha)$ yaitu $0.032<0.05$, maka memberikan penjelasan bahwa variabel $\mathrm{X}_{7}$ mempunyai pengaruh signifikan terhadap return saham sektor property dan real estate. Sedangkan, nilai 
Kadek Ayu Silvia Yuliaratih, dan Luh Gede Sri Artini. Variabel-variabel yang mempengaruhi...

koefisien yang bertanda Positif (+) dapat diartikan bahwa variabel $\mathrm{X}_{7}$ berpengaruh secara positif terhadap return saham sektor property dan real estate, dengan demikian menolak Ho dan menerima $H_{7}$.

Variabel $\mathrm{X}_{8}$ pada tabel 3 mempunyai nilai signifikan sebesar 0,001 dan nilai koefisiennya sebesar 0.004. Penelitian ini alpha $(\alpha)$ yang digunakan adalah 5\% (0.05). Variabel $\mathrm{X}_{8}$ mempunyai nilai signifikan lebih kecil dibandingkan alpha $(\alpha)$ yaitu $0.001<0.05$, maka memberikan penjelasan bahwa variabel $\mathrm{X}_{8}$ mempunyai pengaruh signifikan terhadap return saham sektor property dan real estate. Sedangkan, nilai koefisien yang bertanda Positif (+) dapat diartikan bahwa variabel $\mathrm{X}_{8}$ berpengaruh secara positif terhadap return saham sektor property dan real estate, dengan demikian menolak Ho dan menerima $H_{8}$.

Tabel 4.

Koefisien Determinasi

\begin{tabular}{|c|c|c|c|c|c|}
\hline Model & $\mathrm{R}$ & $\mathrm{R}$ Square & $\begin{array}{c}\text { Adjusted R } \\
\text { Square }\end{array}$ & $\begin{array}{c}\text { Std. Error of } \\
\text { the Estimated }\end{array}$ & $\begin{array}{c}\text { Durbin } \\
\text { Watson }\end{array}$ \\
\hline 1 & .930 & .865 & .856 & .41903 & 2.014 \\
\hline
\end{tabular}

Sumber : Data diolah, 2017

Tabel 4 menggambarkan variabel-variabel secara statistik dalam penelitian ini.Hasil uji Adjusted $R 2$ pada penelitian ini diperoleh nilai sebesar 0,856. Hal inimenunjukkan bahwa ReturnSaham dipengaruhi oleh Produk Domestik Bruto (PDB), Nilai tukar (Kurs), suku bunga (SBI), inflasi, Return On Asset (ROA), Net Profit Margin (NPM), Earning Per Share (EPS) dan Price Earning Ratio (PER)sebesar 85,6\% sedangkan sisanya sebesar 14,4\% dipengaruhi oleh faktor lain yangtidak diteliti dalam penelitian ini. 
Nilai koefisien regresi variabel Produk Domestik Bruto (PDB)sebesar 0,004 menunjukkan apabila Produk Domestik Bruto (PDB)mengalami peningkatan sebesar satu satuan, maka return saham akan meningkat sebesar 0.004 dengan asumsi variabel lain konstan. Hal ini mengindikasikan bahwa Produk Domestik Bruto (PDB)dan return saham menujukkan hubungan yang searah (positif) artinya setiap kenaikan Produk Domestik Bruto (PDB)akan diikuti oleh kenaikanreturn saham. Sebaliknya, setiap penurunan Produk Domestik Bruto (PDB)akan mengakibatkan penuruananreturn saham. Nilai probabilitas (Sig.) t hitung variabel Tingkat Suku Bunga SBI sebesar 0,030 artinya nilai tersebut lebih kecil dari alpha $0,05(0,030<$ 0,05), sehingga variabel Produk Domestik Bruto (PDB)memiliki pengaruh signifikan terhadap return saham. Oleh karena itu, $\left(H^{1}\right)$ diterima.

Nilai koefisien regresi positif $(0,004)$ menunjukkan arah hubungan kedua variabel tersebut positif. ReturnSahamsensitif terhadap Peningkatan PDB dengan arah positif yang menunjukkan perubahan . Return Sahamakan meningkat maka Suku Bunga juga meningkat.

Nilai koefisien regresi negatif (0,001)menunjukkan arah hubungan kedua variabel tersebut negatif. ReturnSahamsensitif terhadap Nilai Tukar (Kurs)dengan arah negatif yang menunjukkan perubahan . Return Sahamakan meningkat makaNilai Tukar (Kurs)akan menurun.

Hasil penelitian menunjukkan bahwa melemahnya (menurunnya) nilai tukar rupiah terhadap mata uang asing (dollar Amerika) berdampak negatif terhadap pasar 
Kadek Ayu Silvia Yuliaratih, dan Luh Gede Sri Artini. Variabel-variabel yang mempengaruhi...

ekuitas, sehingga menyebabkan pasar modal tidak memiliki daya tarik. Hal ini menyebabkan investor beralih ke pasar uang karena return keuntungan yang diperoleh di pasar uang lebih besar daripada di pasar modal yang pada akhirnya menurunkan return saham yang terdapat pada bursa. Hasil ini sesuai dengan penelitian yang dilakukan oleh Ouma, Muriu (2014), Onono (2014) yang memberikan hasil nilai tukar berpengaruh negative signifikan terhadap return saham.

Nilai koefisien regresi variabel Tingkat Suku Bunga SBI sebesar 0,070 menunjukkan apabila Tingkat Suku Bunga SBI mengalami peningkatan sebesar satu satuan, maka return saham akan meningkat sebesar 0.070dengan asumsi variabel lain konstan. Hal ini mengindikasikan bahwa Tingkat Suku Bunga SBI dan return saham menujukkan hubungan yang searah (positif) artinya setiap kenaikan Tingkat Suku Bunga SBIakan diikuti oleh kenaikanreturn saham. Sebaliknya, setiap penurunan Tingkat Suku Bunga SBIakan mengakibatkan penuruananreturn saham. Nilai probabilitas (Sig.) t hitung variabel Tingkat Suku Bunga SBI sebesar 0,715 artinya nilai tersebut lebih besar dari alpha $0,05(0,715>0,05)$, sehingga variabel Tingkat Suku Bunga SBItidak memiliki pengaruh signifikan terhadap return saham. Oleh karena itu, $\left(H^{3}\right)$ ditolak

Hasil penelitian menunjukkan bahwa tingginya tingkat suku bunga tidak berdampak pada menurunnya penjualan saham sektor property dan real estate. Investor tidak tertarik dengan tingkat suku bunga yang tinggi dan investor lebih memilih untuk menginvestasikan modal nya ke sector property dan real estate karena 
investor menganggap keuntungan yang diperoleh dari suku bunga, sifatnya adalah keuntungan jangka pendek dan returnnya kecil. Investor lebih tertarik menginvestasikan modalnya kedalam sektor property dan real estate karenaberanggapan bahwa untuk jangka panjang investasi di sektor properrty akan lebih menjanjikanyang berarti akan memperoleh keuntungan jadiwalaupun tingkat suku bunga meningkat investor tetap tidak menarik dananya.

Nilai koefisien regresi variabel Inflasi sebesar -0,160 menunjukkan apabila Inflasi mengalami peningkatan sebesar satu satuan, maka return saham akan menurun sebesar -0,160 dengan asumsi variabel lain konstan. Hal ini mengindikasikan bahwa Inflasi dan return saham menujukkan hubungan yang tidak searah (negatif) artinya setiap kenaikan Inflasi akan diikuti oleh penurunan returnsaham. Sebaliknya, setiap penurunan inflasi akan mengakibatkan kenaikan return saham. Nilai probabilitas (Sig.) t hitung variabel inflasi sebesar 0,003 artinya nilai tersebut lebih kecil dari alpha $0,05(0,003>0,05)$, sehingga variabel inflasi memiliki pengaruh signifikan terhadap return saham. Oleh karena itu, $\left(H^{4}\right)$ diterima.

Hal ini berarti jika semakin besar variabel ini menunjukkan laba yang dapat dihasilkan dari seluruh kekayaan yang dimiliki juga besar. Hal tersebut akan sangat menarik investor untuk berinvestasi sebab profitabilitas akan mempengaruhi harga saham dan dengan banyaknya investor yang berminat untuk berinvestasi maka akan menyebabkan naiknya harga saham yang mempengaruhi juga terhadap returnyang diterima oleh investor. 
Kadek Ayu Silvia Yuliaratih, dan Luh Gede Sri Artini. Variabel-variabel yang mempengaruhi...

Nilai koefisien regresi variabel Return On Asset (ROA) sebesar 0,008 menunjukkan apabila Return On Asset (ROA) mengalami peningkatan sebesar satu satuan, maka return saham akan meningkat sebesar 0.008 dengan asumsi variabel lain konstan. Hal ini mengindikasikan bahwa Return On Asset (ROA) dan return saham menujukkan hubungan yang searah (positif) artinya setiap kenaikan Return On Asset (ROA) akan diikuti oleh kenaikanreturn saham. Sebaliknya, setiap penurunanReturn On Asset (ROA)akan mengakibatkan penurunan return saham. Nilai probabilitas (Sig.) t hitung variabel inflasi sebesar 0,321 artinya nilai tersebut lebih besar dari alpha 0,05(0,032>0,05), sehingga variabel Return On Asset (ROA) tidak memiliki pengaruh signifikan terhadap return saham. Oleh karena itu, $\left(H^{5}\right)$ ditolak.

Hal inimenunjukkan bahwa perusahaan dengan kondisireturn on asset yang baik atau meningkat pada perusahaan tidak berpotensi terhadap daya tarik perusahaan oleh investor. Investor mempunyai keyakinan potensi saham pada perusahaan akan membaik meskipun pada suatu saat profitabilitas sedang tidak baik. Kondisi ini membuat harga saham perusahaan tersebut menjadi meningkat sehingga peningkatan return on asset tidak akan berdampak pada return saham perusahaan.

Nilai koefisien regresi variabel Net Profit Margin (NPM)sebesar 0,007 menunjukkan apabila Net Profit Margin (NPM) mengalami peningkatan sebesar satu satuan, maka return saham akan meningkat sebesar 0.007 dengan asumsi variabel lain konstan. Hal ini mengindikasikan bahwa Net Profit Margin (NPM) dan return 
saham menujukkan hubungan yang searah (positif) artinya setiap kenaik Net Profit Margin (NPM)akan diikuti oleh kenaikanreturn saham. Sebaliknya, setiap penurunanNet Profit Margin(NPM) akan mengakibatkan penurunan return saham. Nilai probabilitas (Sig.) t hitung variabelNet Profit Margin(NPM) sebesar 0,000 artinya nilai tersebut lebih besar dari alpha $0,05(0,000<0,05)$, sehingga variabel $\mathrm{Net}$ Profit Margin (NPM)memiliki pengaruh signifikan terhadap return saham. Oleh karena itu, $\left(H^{6}\right)$ diterima.

Hal ini menunjukkan bahwa perusahaan dengan kemampuan perusahaan menghasilkan pendapatan bersihnya terhadap total penjualan yang dicapai mempengaruhi investor untuk masuk sehingga sahamnya di pasar bursa banyak diburu pembeli. Peningkatan permintaan terhadap saham dapat mempengaruhi harga saham tersebut, sehingga hal ini berdampak terhadap return saham.

Nilai koefisien regresi variabel Earning Per Share (EPS)sebesar 0,003 menunjukkan apabila Earning Per Share (EPS)mengalami peningkatan sebesar satu satuan, maka return saham akan meningkat sebesar 0.003 dengan asumsi variabel lain konstan. Hal ini mengindikasikan bahwa Earning Per Share (EPS) danreturn saham menujukkan hubungan yang searah (positif) artinya setiap kenaikProduk Earning Per Share (EPS)akan diikuti oleh kenaikanreturn saham. Sebaliknya, setiap penurunan Earning Per Share (EPS)akan mengakibatkan penurunan return saham. Nilai probabilitas (Sig.) t hitung variabel Earning Per Share (EPS) sebesar 0,032 artinya nilai tersebut lebih besar dari alpha $0,05(0,032<0,05)$, sehingga variabel 
Kadek Ayu Silvia Yuliaratih, dan Luh Gede Sri Artini. Variabel-variabel yang mempengaruhi...

Earning Per Share (EPS)memiliki pengaruh signifikan terhadap return saham. Oleh karena itu, $\left(H^{7}\right)$ diterima.

Hal inimenunjukkan bahwa sebagian besar perusahaan Property dan Real Estatemengalami peningkatan earning per share setiap tahunnya. Tahun 2008-2011 rata-rata perusahaanmengalami kenaikan laba bersih. Meskipun ada beberapa perusahaanyang menambah jumlah saham beredar namun persentase kenaikannya lebih rendah dari pada persentase kenaikan laba bersih sehingga perusahaan tetap mampu meningkatkan angka laba per lembar sahamnya. Semakin tinggi Earning Per Share (EPS)menandakan semakin baik pula kinerja perusahaan dimata investor sehingga informasi ini direspon positif oleh investor. Investor menganggap bahwa peningkatan EPS merupakan sinyal yang baik karena menggambarkan peningkatan prospek perusahaan kedepannya dan dapat digunakan sebagai parameter yang mempengaruhi return saham.

Nilai koefisien regresi variabel Price Earning Ratio (PER)sebesar 0,004 menunjukkan apabila Price Earning Ratio (PER)mengalami peningkatan sebesar satu satuan, maka return saham akan meningkat sebesar 0.004 dengan asumsi variabel lain konstan. Hal ini mengindikasikan bahwa Price Earning Ratio (PER)dan return saham menujukkan hubungan yang searah (positif) artinya setiap kenaikPrice Earning Ratio (PER)akan diikuti oleh kenaikanreturn saham. Sebaliknya, setiap penurunan Price Earning Ratio (PER)akan mengakibatkan penurunan return saham. Nilai probabilitas (Sig.) t hitung variabel Price Earning Ratio (PER) sebesar0,001 
artinya nilai tersebut lebih kecil dari alpha $0,05(0,001<0,05)$, sehingga variabel Price Earning Ratio (PER)memiliki pengaruh signifikan terhadap return saham. Oleh karena itu, (8) diterima.

Hal ini menunjukkan bahwa prospectus harga saham dinilai semakin tinggi oleh investor terhadap pendapatan perlembar sahamnya, sehingga Price Earning Ratio (PER) yang semakin tinggi juga menunjukkan semakin mahal saham tersebut terhadap pendapatannya. Jika harga saham semakin tinggi maka selisih harga saham periode sekarang dengan periode sebelumnya semakin besar, sehingga return saham juga semakin meningkat.

\section{SIMPULAN DAN SARAN}

Penelitian yang dilakukan dengan menjelaskan hubungan kausal antara variabel-variabel yang mempengaruhi return saham, diperoleh hasil sebagai berikut : 1). Terdapat pengaruh positif dan signifikan Produk Domestik Bruto (PDB), Net Profit Margin (NPM), Earning Per Share (EPS), dan Price Earning Ratio (PER) terhadap Return Saham pada perusahaan property dan real estate yang terdaftar di BEI periode 2012-2016. Hal ini menunjukan bahwa pengaruh Produk Domestik Bruto (PDB), Net Profit Margin (NPM), Earning Per Share (EPS), danPrice Earning Ratio (PER) mempengaruhi searah dengan Return Saham; 2). Terdapat pengaruh negative dan signifikan antara Nilai tukar .rupiah (Kurs) dan Inflasi terhadap Return Saham pada perusahaan property dan real estate yang terdaftar di BEI periode 2012-2016. Hal ini menunjukanbahwa pengaruh Nilai Tukar dan Inflasi 
Kadek Ayu Silvia Yuliaratih, dan Luh Gede Sri Artini. Variabel-variabel yang mempengaruhi...

mempengaruhi berlawanan dengan Return Saham; 3). Terdapat pengaruh positif dan tidak signifikan suku bunga (SBI) dan Return On Assets (ROA) terhadap Return Saham pada perusahaan property dan real estate yang terdaftar di BEI periode 20122016. Hal ini menunjukan bahwa pengaruh suku bunga SBI dan Return On Assets (ROA) tidak mempengaruhi dan berlawanan dengan return saham.

Beberapa saran yang dapat digunakan sebagai bahan pertimbangan dalam melakukan investasi di pasar modal, khususnya dalam berinvestasi saham adalah sebagai berikut: Bagi Investor dan calon investor Penelitian ini menunjukkan bahwa Produk Domestik Bruto (PDB), Net Profit Margin (NPM), Earning Per Share (EPS), Price Earning Ratio (PER) berpengaruh signifikan terhadap return saham, sehingga variabel-variabel tersebut perlu diperhatikan dalam menilai suatu perusahaan. Selain itu variabel-variabel tersebut dapat dijadikan pertimbangan dalam pengambilan keputusan

Bagi penelitian selanjutnya : 1). Untuk penelitian selanjutnya diiharapkan menggunakan atau menambahkan variabel lain yang mempengaruhi return saham misalnya, Operating Income (OI), Market Value Added (MVA), Debt to Equity Ratio (DER), Return On Equity (ROE), atau Price to Book Value (PBV); 2). Penelitian selanjutnya diharapkan menambah periode penelitian agar diperoleh hasil yang lebih akurat mengenai return saham. 


\section{REFERENSI}

Aloysius, Harry Sulistyo. 2004. Analisis Faktor Fundamental Perusahaan terhadap Total Return Di Bursa Efek Jakarta. Tesis Magister Manajemen Universitas Diponegoro

Arista, Desi. 2012. Analisis Faktor Faktor Yang Mempengaruhi Return Saham (Kasus Pada Perusahaan Manufaktur yang Go Public di BEI periode tahun 2005-2009). Jurnal Ilmu Manajemen dan Akuntansi Terapan.Vol. 3, No. 1, Mei 2012.

Chen Zhang Ganesh. 2006. Financial Distress Predicton in China. Review of Pacific Basic Financial Markets and Policies.Vol. 9, Iss. 2,p: 317

Chiarella C. and Gao S. (2004), The Value of The S\&P 500 -A Macro View Of The Stock Market Adjustment Process" Global Finance Journal. 15:171-196.

Christanty, Mila. 2009. Analisis Pengaruh Faktor Fundamental dan Economic Value Added (EVA) terhadap Return Saham Studi pada Saham Perusahaan yang tercatat Aktif dalam LQ 45 di BEI Periode 2003- 2007. Tesis Program Pasca Sarjana Magister Manajemen Universitas Diponegoro.

Dahlan Siamat, 2005. Manajemen Lembaga Keuangan. "Kebijakan Moneter dan Perbankan", Jakarta : Fakultas Ekonomi Universitas Indonesia, edisi kesatu.

Eljelly A, Alghurair K. 2001. Performance Measures and Welth Creation in An Emerging Market: The Case of Saudi Arabia. International Journal of Commerce and Management.Vol. 11, No. 3-4

Garzha, J. G. (2010). International Determinants of Stock Market Performance in China: A Cointegration Approach. University Of The West England.

Haghiri, Amir and Haghiri Soleyman. 2012. The Investigation of Effective Factors on Stock Return with Emphasis on ROA and ROE Ratios in Tehran stock exchange (TSE), Journal of Basic and Applied Scientific Research. 2 (9) 9097 9103 
Kadek Ayu Silvia Yuliaratih, dan Luh Gede Sri Artini. Variabel-variabel yang mempengaruhi...

Harjito, D. Agus dan Aryayoga, Rangga. 2009. Analisis Pengaruh Kinerja Keuangan dan Return saham di Bursa Efek Jakarta, jurnal fenomena, hal. 13-21 ISSN 1693-4296.Volume 7, Nomor 1.

Hardiningsih, Pancawati. 2009. Determinan Nilai Perusahaan. Jurnal JAI, Vol.5, No.2, Juli 2009: 231-250. Semarang.

Hayat, Yasmeen dan Syed Nisar Ahmed, (2014), Impact of Inflation on Stock Ex change Market Returns, European Aca demic Research, Vol. I, Issue 11/ February 2014.

Henry Simamora. Akuntansi Basis Pengambilan Keputusan Bisnis. Jilid 1. Salemba Empat : Jakarta,2000.

Hooker, Mark A. (2004), "Macroeconomic Factors and Emerging Market Equity Returns: A Bayesian Model Selection Approach”, Emerging Markets Review, 5, pp.379- 387.

I.G.K.A Ulupui, (2005). Analisis Pengaruh Rasio Likuiditas, Leverage, Aktivitas dan Probabilitas Terhadap Return Saham (Studi Pada Perusahaan Makanan dan Minuman dengan Kategori Industri Barang Konsumsi di BEI, Jurnal Akuntansi Fakultas Ekonomi, Universitas Udayana.

Kirui, Evans, Nelson H. W. Wawire \& Perez O. Onono, (2014), Macroeconomic Varia bles, Volatility and Stock Market Returns: A Case of Nairobi Securities Exchange, Kenya, International Journal of Econo mics and Finance; Vol. 6, No. 8.

Machfoedz, 1994, Pengaruh Rasio Keuangan Terhadap Perubahan Laba, Jurnal Riset Akuntansi Indonesia.

Malintan, Rio. 2013. Pengaruh Current Ratio (CR), Debt To Equity Ratio (DER), Price Earning Ratio (PER), DAN Return On Asset (ROA) Terhadap Return Saham Perusahaan Pertambangan Yang Terdaftar Di Bursa Efek Indonesia Ttahun 2005-2010. Jurnal Ilmiah Universitas Brawijaya. 
Maryanne, Donna Menina Della. 2009. "Pengaruh Nilai Tukar Rupiah, Suku Bunga SBI, Volume Perdagangan Saham, Inflasi dan Beta Saham Terhadap Harga Saham". Tesis, Program Pascasarjana Magister Manajemen Universitas Diponegoro.

Natarsyah, Syahib, 2000, Analisis Pengaruh Beberapa Faktor Fundamental dan Risiko Sistematik Terhadap Harga Saham: Kasus Industri Barang Konsumsi yang Go Publik di Pasar Modal Indonesia, Jurnal Ekonomi dan Bisnis, Vol. 15 No. 3 Hal. 294-312.

Nathaniel, Nicky, 2008. “Analisis Faktor-Faktor yang Mempengaruhi Return Saham (Studi pada Saham-Saham Real Estate And Property di Bursa Efek Indonesia Periode 2004-2006)", Tesis.Semarang: FE UNDIP

Onwukwe, E. K., \& Okwuchukwu, O. (2014).Stock Market Return Volatility and Macroeconomic Variables in Nigeria. International Journal of Empirical Finance, Vol. 2 No. 2 :75- 82.

Ouma, Wycliffe Nduga, Dr. Peter Muriu, (2014), The impact of macroeconomic variables on stock market returns in Kenya, International Journal of Business and Commerce Vol. 3, No.11: July.

Prihatini, Ratna, 2009. Tesis: Analisis Pengaruh Inflasi, nilai Tukar, ROA, DER dan CR Terhadap Return Saham.

Sangkyun, Park, 1997, "Rationality of negative Stock Price Responses to Strong Economics Activity”Journal Financial Analyst, Sept/Oct 1997.

Septiana Rizky Kusumastuti, 2009. Pengaruh Faktor Fundamental Perusahaan dan Faktor Makro terhadap Return Saham

Sugeng Mulyono. 2000. Pengaruh EPS dan Tingkat Bunga Terhadap Harga Saham.Jurnal Ekonomi dan Manajemen.

Sunarto, 2001.'Pengaruh Rasio Profitabilitas dan Leverage Terhadap Return Saham Perusahaan Mnufaktur di BEJ”. Jurnal Bisnis dan Ekonomi

Suteja, Jaja dan Patrisius Seran. 2015. Determinan Return Saham Industri Otomotif dan Komponen yang Terdaftar di BEI. Trikomika, 14 (1): 76-86. 
Kadek Ayu Silvia Yuliaratih, dan Luh Gede Sri Artini. Variabel-variabel yang mempengaruhi...

Syarofi, Faris Hamam. (2014). Analisis Pengaruh Suku Bunga SBI, Kurs Rupiah/ US\$, Harga Minyak Dunia, Harga Emas Dunia, DJIA, Nikkei 225 dan Hang Seng Index terhadap IHSG dengan Metode Garch-M.Skripsi, Semarang: Program Sarjana Universitas Diponegoro

Tendysius, Harry Sulistyo. 2004. Analisis Faktor Fundamental Perusahaan terhadap Total Return Di Bursa Efek Jakarta. Tesis Magister Manajemen Universitas Diponegoro.

Thobarry, A.A. 2009. Analisis Pengaruh Nilai Tukar, Suku Bunga, Laju Inflasi dan Pertumbuhan GDP Terhadap Indeks Harga Saham Sektor Properti (Kajian Empiris Pada Bursa Efek Indonesia Periode Pengamatan Tahun 20002008).Tesis Program Pascasarjana Universitas Diponegoro. Semarang.

Utami, Mudji dan Rahayu, Mudjilah, 2003.Peranan Profitabilitas, Suku Bunga, Inflasi Dan Nilai Tukar Dalam Mempengaruhi Pasar Modal Indonesia Selama Krisis Ekonomi. Jurnal Manajemen dan Kewirausahaan. Vol. 5 No. 2 September.

Yeye Susilowati. 2011. Reaksi signal rasio profitabilitas dan rasio solvabilitas terhadap return saham perusahaan di perusahaan sektor manufaktur yang terdaftar di BEI.Jurnal Dinamika dan Perbankan ISSN 1979-4878 Vol. 17-37. 